ICAMS 2016 $-6^{\text {th }}$ International Conference on Advanced Materials and Systems

UNCONVENTIONAL COSTUME COLLECTION INSPIRED BY THE BRANCUSI ART. FROM THE ENDLESS COLUMN TO THE ENDLESS DRESS

\author{
ALINA MIHAELA GURGU $\breve{A}$ \\ National University of Arts - Bucharest, 19 General Budisteanu St., n_alina_m@yahoo.com
}

\begin{abstract}
Opinions about the complexity of the Brancusi inspiration sources revealed that the sculptor statuary is a transcript, in a modern manner, of the influence at a stylistic and thematic level that Romanian folklore and folk art have exercised over his artistic genius. Starting from various native elements found in the sculptor's work, a shift was made from the shape of the popular objects, from the functionality and the decorative intimacy of the peasant interiors, directly connected with the spirituality and the ancient background, to the artistic essentialization and conceptualization characteristic to Brancusi. A transposition of Brancusi's work characteristic elements in an unconventional costume was achieved with the personal collection, through various experiments, modifying the materiality, the texture, the volumetry, the color and the transparency. Using the derridean example, the Endless Column became the Endless Dress. The garment - objects collection "Endless Dress", in its various versions, worked equally for fashion shows, costume exhibitions and for a play staged on "Masca" Theatre in Bucharest. The present research is an example of transposition of the high Romanian cultural spirituality in fashion and costume, which certainly may go further through stylization and simplification in a more functional, commercial direction, explored by the local creative industries.
\end{abstract}

Keywords: Brancusi, fashion, theatre

\title{
INTRODUCTION
}

Constantin Brancusi, the sculptor, an artist known worldwide, gave mankind creations materialized in an universal sculpture language, which were and still are loved and understood by a wide audience, upon whom produces a unique fascination. His creative genius has given a new brilliance to the ancient world of ideas and universal truths, has updated myths to the contemporary acceptance and thinking level in new spiritual forms. Brancusi appealed to essences in order to communicate philosophical ideas from the past thinking, bringing them to the modern and optimist spirit of the civilized man, hoping his works will express confidence in life and open the men souls to beautiful.

In the cultural context that followed Brancusi's creation, where the work of the great artist was base of inspiration for several art fields, appeared the interest for a personal interpretation of Brancusi's sculptures.

The "Endless dress" project had from the start as purpose the reinterpretation of Brancusi's sculptures through a garment-objects collection, preserving the balance between shape, proportions, volumes and fabrics.

\section{THEORETICAL HIGHLIGHTS}

A starting point for this research was the personal fascination for the Romanian sculpture, Constantin Brancusi, and especially for the "Endless Column", opera situated in the center of his artistic creation.

Resorting to many Brancusi's exegetes writings on symbolism and significance of the artist's sculptures, a rigorous documentation was made, which served as the foundation for a modern unconventional interpretation. 
Brancusi appealed to essences in order to communicate ideas of the past philosophical thinking, bringing them towards the modern and optimistic civilized man spirit and by keeping the proportions, it has been attempted, through stylization and essentialization, a transposing of the "Endless Column" polyvalent symbolism in garment-objects.

"Endless Column" amazes with its litheness and produces admiration to anyone is given to see it: "When you look at this column in a photographic reproduction, it's hard to penetrate the strong sense of energy, the closed vigor into it," said after a trip to Targu Jiu, Mario Michelli, Italian writer and art critic. He continues: "Only when I saw it so high, strong and right springing up suddenly, without pedestal, from the empty plain, it seemed that I snatched, that I understood at once all the Brancusi's secret art".

Watching the "Endless Column", there is this impression of infinite succession, the idea of repetition, for the rhomboid overlapping is not isolated, nor accidental. The same phenomenon can be seen in "Portrait of James Joyce", "Socrates", "King of kings", the artist oscillating between spiral and overlapping on an axis having a clear idea of becoming and perpetual return in a cycle that is endlessly repeated. Each column's octahedron represents the end and beginning of each other, so that the work suggests a scale of generations, ages, years or moments; a relentless ascent.

The "Endless Column" rises directly from the ground to the blue sky, where is lost in the infinite, conquering space, becoming a new interpretation of the Universe with its sublime. This artwork is imprinted a continuous movement, life and glow.

"At Brancusi, form and light merge. It's hard to say what is most important in sculptor's thinking. Both, however, shape and light are the most direct ways of communication.

The extraordinary mastery, reality contingent, discovering new monumental meanings, spiritual integrating modern sculpture in architecture, transformation of the sculpture into a hotbed light as the source of movement and life, have opened unexpected perspectives within this art", wrote Mircea Deac, in "Brancusi, archetypal sources".

Mircea Deac also reminded several discussions and interpretations of "Endless Column", essential symbol of Brancusi's creation: “... celestial and aerial trees of admirable proportions", says Professor Sigfried Giedion; "a giant cactus in the deserts of California," wrote Malvina Hoffman; " a chain of perpetual kinks and rebirth," added Andre Frenaud.

Petru Comarnescu considered "Endless Column" as inspired by the Gorj porches rhomboid pillars and "... designed to suggest in the wide space an infinity of human forms, shapes of birds and jugs, protrusions and eaves of rocks, towering in the horizon heaven".

Brancusi himself considered that of all columns he made only one made it to rise up to heaven and confessed that through it finally reached perfection. He resembled it with "a song that leads to eternal infinity beyond all pain and factual joy".

\section{THE RESEARCH METHODOLOGY}

An important first step towards the concept of sculptural expression of the costume made Brancusi himself in 1922, when for the ballet "Gymnopedies" staged by the nonconformist dancer, Lizica Codreanu, music by Erik Satie, he imagined a head accessory referring to "Witch", a wood sculpture. Some have found symbolism in 
ICAMS 2016 $-6^{\text {th }}$ International Conference on Advanced Materials and Systems

romanian witches tales and others in the book "La Sorcierese" - Jules Michelet, for they knew clearly that this writing was on the Brancusi's library shelves.

Taking a leap into the future, 140 years since the birth of the great artist who brought a new vision in the universal plastic language, the essence of things is being celebrated, whether in Targu Jiu, Bucharest, Paris, London or New York.

In fashion, the sculptor's works, but also the artist status and personality have inspired great designers to create clothes, shoes and accessories.

The Haute Couture collection signed by Valentino once again confirmed the strong symbolism of Brancusi's works, in this case being about accessories. Creations with retro shapes and most varied materials, from leather to cashmere and fur, were inspired by Romanian sculptor's Prometheus or The New Born.

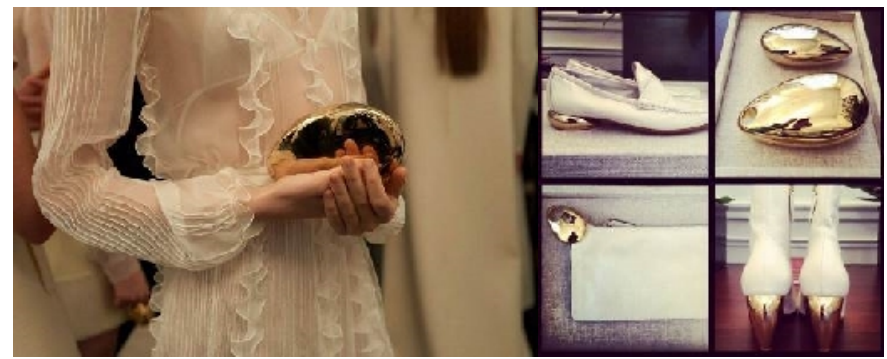

Figure 1. Valentino, New York, 2014

Rick Owens creations had as inspiration source The Kiss symbol, the two halves of the circle found on the faces of each column gate.

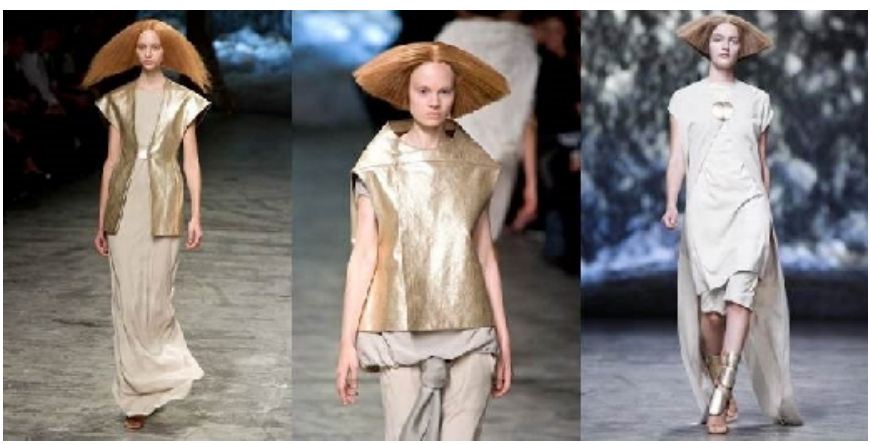

Figure 2. Rick Owens, ss 2013

Lilly Heine relied on structure, volumetric and architectural lines. The aim behind her collection was to give life to the sculptures with the body motion of the models. 


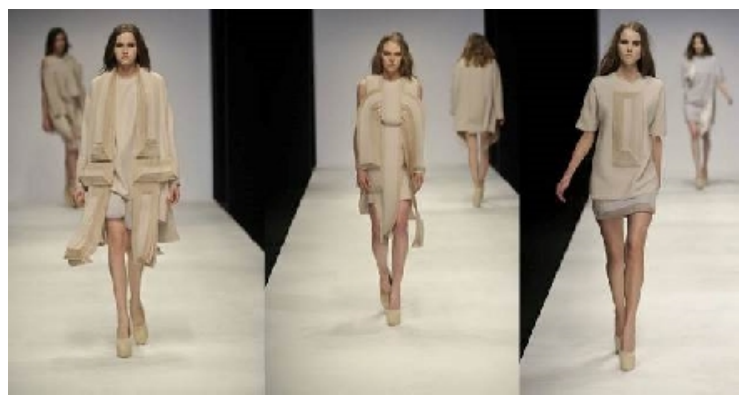

Figure 3. Lilly Heine, ss 2013

Also inspired by Brancusi's sculptures, Musette shoes and handbags for summer 2015 had one thing in common: bright golden skin, which remind the bronze works of the artist.

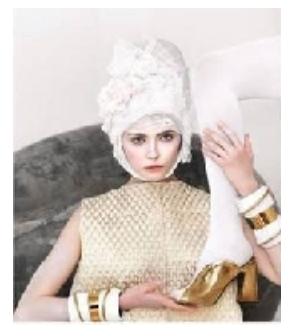

Figure 4. Musette, ss 2015

\section{EXPERIMENTS, RESULTS AND DISSCUSIONS}

"Endless dress" is a timeless garment-objects collection, including ten outfits with a rigorous image. The cut is precise, with straight lines and complex volumes resulting from unfolding of simple rhomboid forms, attention being directed to the clean and cared execution. However this strictness from the cutting is sometimes attenuated by the introduction of embroidery details obtained through various techniques of felting.

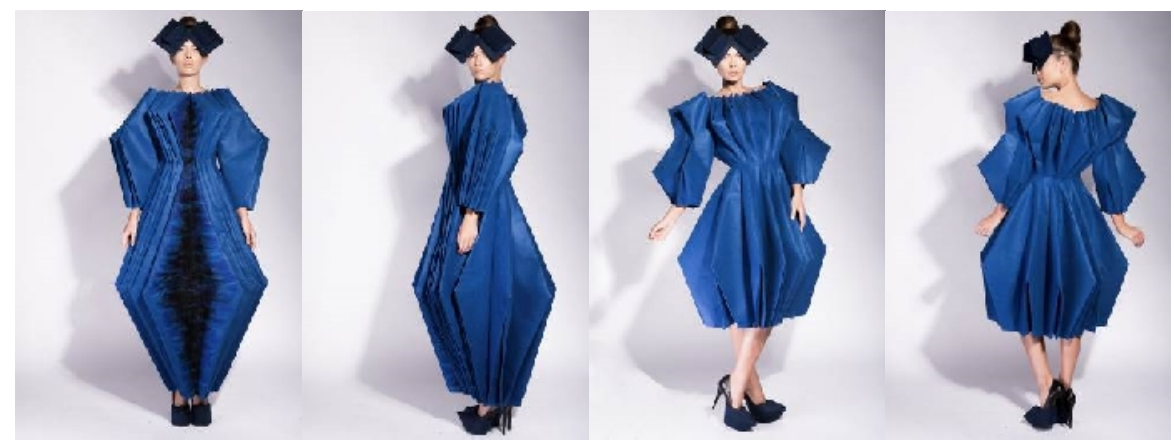

Figure 5. "Endless Dress", Alina Gurgu ă 
For the technical realization, the patterns obtaining was made step by step, meaning that once getting the first piece, through numerous molds and corrections, the next one derived from it like the pieces of a telescope. Thus, parts of the first pattern were preserved, and through various additions and other modifications gave birth to other new parts.

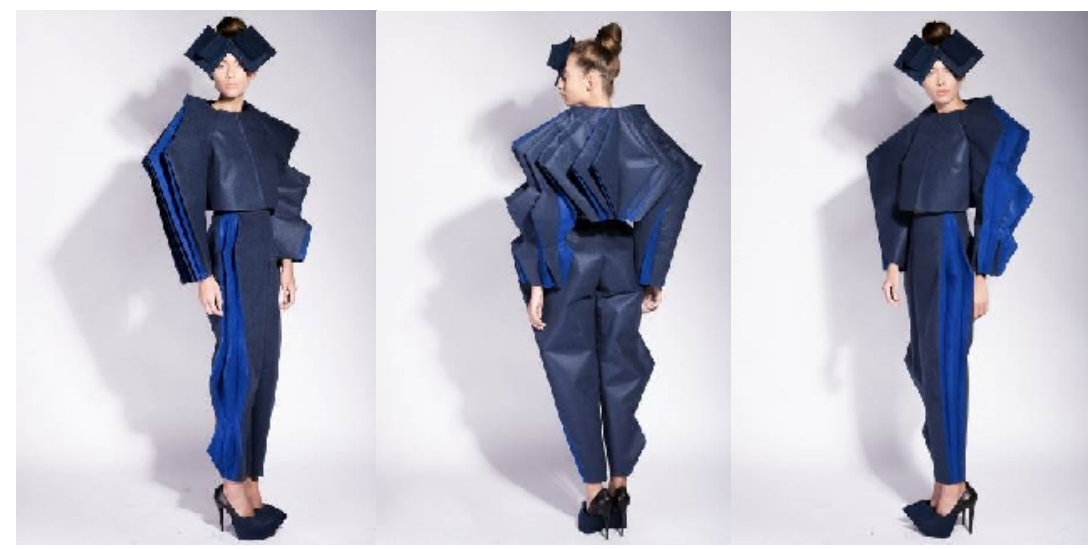

Figure 6. "Endless Dress", Alina Gurgu ă

For the good achievement of all the outfits of "Endless dress" collection, were used both conventional materials (Merino wool, Eugenia lining, etc.) and unconventional (felt, which normally is used to make hats and some accessories like bags or purses). Felt was a choice because of its properties, being a stiff material and helping to produce the pieces according with the patterns and the sketches.

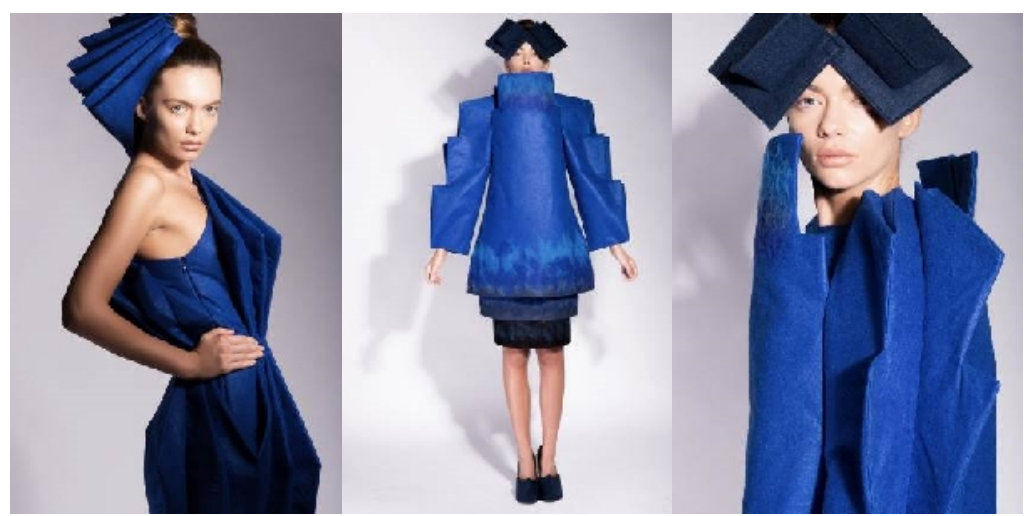

Figure 7. "Endless Dress", Alina Gurgu ă

Endless Dress is Endless Column transposed into garment; is a connection between body and spirit, interior - exterior, clothe - feeling, but also the connection between earth and sky. Borrowing the blue from the sky, chromatic comes to strengthen this meaning. 


\section{CONCLUSIONS}

Brancusi certainly remains an actual artist, for many contemporary artists remember him and his work as inspiration. The artist reinvented sculpture returning to the creative artistic means used in the most remote and primitive arts, creating an universal art, unanimously appreciated, that cannot be erased with the twentieth century.

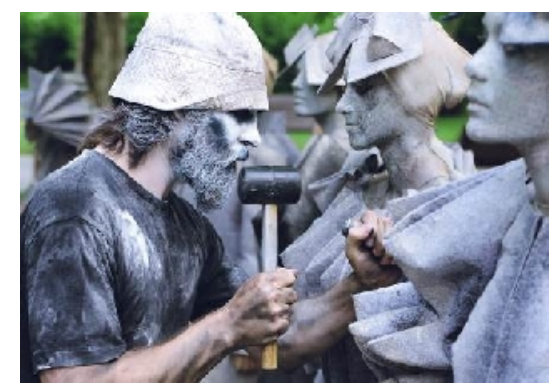

Figure 8. "Endless Dress" play for "Masca" Theatre, Bucharest

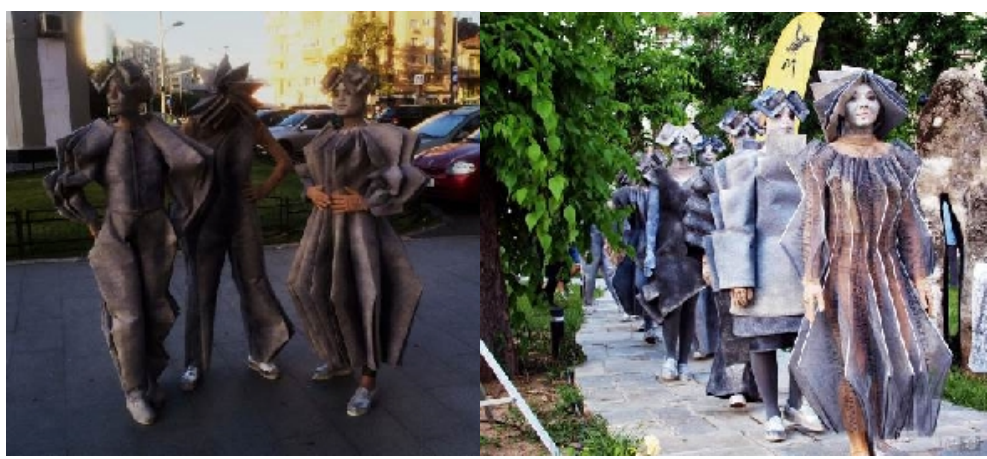

Figure 9. Living Statues "Endless Dress" for "Masca" Theatre, Bucharest

\section{REFERENCES}

Berger, R. (1978), La mutation des signes, Meridiane, Bucharest.

Deac, M. (1982), Brâncuşi. Archetypal Sources, Junimea, Iaşi.

Giedion-Welcker, C. (1981), Constantin Brancusi, Meridiane, Bucharest.

Lemny, D. (2009), Lizica Codreano. Une danseuse roumaine dans l'avant-garde parisiene, Vellant, Bucharest.

Noica, C. (1973), Creation and beauty in Romanian utterance, Eminescu, Bucharest.

Teja Bach, F. (1991), Brancusi. Photo Reflection, Didier Imbert Fine Art, Paris.

Velescu, R.C. (1999), Concepts of Constantin Brancusi's poetics, Univers Enciclopedic, Bucharest. 